The LANCET,] DR. RUFFeR: PREVENTIVE MEDICAL MEASURES AT TOR AND SUEZ. [Dec. 30, 1899. 1801

\section{MEASURES TAKEN AT TOR AND SUEZ AGAINST SHIPS COMING FROM THE RED SEA AND THE FAR EAST. 1}

By MARC ARMAND RUFFER, M.A., M.D. OXON., PRESIDENT OF THE SANITARY, MARITIME, AND QUARANTINE COUNCIN OF RGYPT.

IN the first place I wish to express my thanks to you for the honour you have done me in asking me to read a paper here to-night. I greatly regret that owing to the impossibility of getting leave I shall not be able to read the paper myself or to answer any questions. I can only say that if any member wishes to have further information with regard to any point raised in this paper I shall be happy to answer his questions by letter if he will communicate with me at Alexandria. I must begin this paper by describing the present state of the sanitary services in Egypt, for it might appear somewhat strange that I criticise regulations which it is my duty to enforce; but, as will be seen, the regulations are not of my own making.

Egypt is the happy possessor of two sanitary services. The first looks after the sanitation of the whole of Egypt and forms one of the departments of the Ministry of the Interior. The second is under the Sanitary, Maritime, and Quarantine Council of Egypt, and on the Council England, Turkey, Spain, Sweden and Norway, Portugal, Belgium, France, Austria, Germany, Denmark, Russia, Greece, Holland and Italy are respectively represented by one delegate, who may or may not be accompanied by a medical adviser. Egypt is represented by the President, the Inspector-General, the Chief Veterinary Inspector of the Sanitary Service, and the Sanitary Inspector of the town of Alexandria. Every one of the nations represented has one vote, whereas Egypt has three. The President, however, has only a casting-vote and can only use it if the votes are equally divided. All the members of the Board, the President and the veterinary inspector excepted, must either be duly qualified medical men or have the rank of viceconsuls, duly belonging to the Consular Service. The President has no control over the Council or over the finances and staff except what his personal influence gives him. He presides at the meetings and executes the decisions of the Council, but he can neither appoint nor dismiss any official or punish him in any way except by permission of the Council. He is not allowed to spend one sou without the leave of a special committee on finance, nor can be make any reform, be it ever so urgent, without the approval of the Council. I take this opportunity of stating that the medical men who are members of the Council have always-at any rate during my term of office-worked with zeal and singular fairness, looking at most questions from a professional point of view. The presence of the consular element on the board is altogether an anomaly, and in my opinion these gentlemen should have no voice in decisions concerning technical questions. It is little short of ridiculous to allow men to interfere in technical questions when from the nature of their occupation they have had no opportunity of acquiring technical knowledge. The decisions of the Council must be in accordance with the decisions of the Convention of Venice; and, indeed, the tendency of late years has been for the Council to apply such measures only as are clearly laid down by that Conference. Whether these measures are altogether satisfactory or logical, whether they accord with the latest ideas regarding the progress of infectious disease, whether they are not rather a halting compromise between the opinion of the extreme quarantinist and that of the pushing shipping agent who would infect the whole of Europe rather than consent to his ship being delayed 10 minutes are questions which need not concern us at present. I would point out, however, that the united wisdom of Europe sitting at Venice has produced a set of regulations in which the same paragraph orders two contradictory measures to be carried out. The interpretation of some of the paragraphs is more or less guess work.

The point which is of interest this evening is the measures

1 A paper read before the Epidemiological Society on Dec. 15th, 1899 . which are being taken to prevent ships which come from the Red Sea and the Far East carrying plague and cholera into Egypt and Europe. The very existence of such regulations shows that Europe tacitly acknowledges the position with regard to preventing the entrance of cholera and plague into any country by quarantine measures. But, as is well known, cholera and plague in spite have passed into Egypt and through the Suez Oanal into Furope. The measures vary according to whether the ships carry pilgrims or ordinary passengers. The ships carrying pilgrims from the Hedjaz are not allowed to go through the Canal or to land Egyptian pilgrims into Egypt until the ship and its passengers have undergone a period of observation at Tor. The pilgrimage or $\mathrm{Hadj}$ is a yearly occurrence and consists in the visit which all good Mahometans are expected to pay, once at least in their lives, to the Caaba at Mecca and to the tomb of their Prophet at Medina. It is attended by Mahometans from all over Europe, Asia, Africa, and large camel caravans used to leave every year for Mecca and Medina. In former years any danger of the pilgrims bringing back plague or cholera was minimised by the long sea or desert journey. Since the introduction of railways and steamers, however, conditions have changed, and were it not for quarantine regulations an Egyptian pilgrim might go from Egypt to Mecca and return to Suez in little more than a fortnight. The number of pilgrims who pass annually through the quarantine camp of Tor varies from 12,000 to 30,000 . The most sacred spot on earth to a Mussulman is the Mosque at Mecca which encloses the Caaba-a black stone which marks the spot where Adam first worshipped on his expulsion from Paradise. It is said to have been placed there by Abraham and Ishmael. Certain it is that it has existed on the spot from time immemorial and served before Mahomet's time for the rites of some idolatrous tribes in the neighbourhood. Since the second year of the Hegira it has been the point to which all followers of the Prophet are expected to turn when at their devotions. Mahomet ordained that it should be visited every year on the 10th of the month, which he fixed as the anniversary of the sacrifice of Isaac and his release at the command of the angel. The second object of the pilgrimage-namely, the visit to Mahomet's tomb at Medina-may be accomplished either before or after this date. As far as El Tor is concerned the pilgrims coming from the West, or Ifecca, are divided into two main divisions, which arrive at the quarantine station at an interval of four or five weeks, one after the other. The first lot comprises the Turks, Algerians, Marocans, as well as Herzegovinians, Servians, and Bulgarians, and a goodly number of people from Asia Minor, the Caucasus, Turkestan, and even far-off Mongolia. A picturesque and motley crew they are, showing features and dresses collected from an area of some 4000 miles in length and embracing stragglers from three continents, all fired with the same religious zeal and bent on the same errand. The second division of the pilgrimage shows less variety of nationality and costume as it consists only of Egyptians and their immediate neighbours the Soudanese, Syrians, \&c. These generally visit Mecca first on the appointed date and afterwards Medina, whence they travel to Yambo where pilgrim ships are supposed to await them to bring them up the Red Sea. The Turkish section, on the other hand, invariably visits the tomb of the Prophet first, then the Caaba at Mecca, and leaves Djeddah for Tor some weeks before the Egyptians leave Yambo. The means of transport of these thousands of devotees is totally inadequate, the overcrowding, want of sanitary arrangements, filth and distress of the people resembling exactly the horrors of the slave-ships of the eighteenth century. Indeed, to those who have been eye-witnesses of the facts it is incredible that such a state of things can be tolerated, and it does not redound to the credit of Christianity to learn that the shipowners who are responsible for such mismanagement are practically all Christians. Each ship is licensed to carry a limited number of passengers at so much a head, but each shipowner makes an illegal profit by embarking nearly double the number of passengers allowed by his licence. Of course, the poor wretches who are congregated by thousands at the port will gladly pay full fare to be taken off at once, even if there is only standing room on the ship; for after the hardships of travel-insufficient food, robbery by Bedouins, \&c.which they have undergone their one thought is to reach home at any cost. Consequently many of the ships, though licensed to carry a certain number of passengers, arrive at DD 2 
Tor with double that number, and the wretched pilgrims are literally crowded like sardines in a tin, there being barely room to lie down on the deck. The scenes of confusion and filth, with the horrors of sea-sickness and other forms of malady, almost defy description. Old steamers are used for this purpose. On one occasion I saw the boat arrive with a crowd of some 30 women packed together outside the paddle-boxes, a mere flimsy wooden barrier being the only obstacle to prevent them falling overboard; had they met with a rough sea the whole lot must have been washed over. The sanitary arrangements considered good enough for these helpless people deserve to be commemorated by photography. They consist merely of large packing-cases slung over the ship's side, and with a hole cut through the bottom. As a rule, however, the crowding is so intense that it is quite impossible for the pilgrims to reach even these primitive arrangements; and as quite 50 per cent. of the people suffer from diarrhœa they relieve themselves anywhere as best they may. The overcrowding is so great that it is not uncommon to find dead people, lying in the midst of their fellows, covered with fæces and urine. Let it be said at once that the few steamers belonging to the Austrian lines which carry on this traffic are a brilliant exception. The. Austrian Government has imposed such heary penalties on their captains for overcrowding, \&c., that their ships are almost perfect from a sanitary point of view. There is some hope that some remedy will be found shortly for the state of things on other boats. Each pilgrim ship carries a medical man; but even should he wish to do so he is quite unable to do anything. For instance, when a death occurs on the way there is reason to fear that the body is thrown overboard and the death stoutly denied. When the death occurs in or near the harbour the captain resorts to the quaintest expedients to hide the corpse, such as hanging it over the side of the ship, \&c. It is a peculiar fact that although most of the medical men stoutly deny having had a death between Jeddah and Tor two or three pilgrims invariably die witbin a few hours of their arrival at Tor. The captain takes as many passengers as he can possibly get on board. In most cases he apparently makes a guess as to the number of people and enters a certain number on the bill of lading; but this number is invariably wrong, as the following table will show:-

Year 1898.

\begin{tabular}{|c|c|c|c|c|c|c|}
\hline \multicolumn{5}{|c|}{ Nationality of ship. } & \multirow{2}{*}{$\begin{array}{l}\begin{array}{l}\text { Number of } \\
\text { pilgrims on } \\
\text { ship's books. }\end{array} \\
551\end{array}$} & $\begin{array}{l}\text { Number actually } \\
\text { found. }\end{array}$ \\
\hline Tarkish ... & $\ldots$. & $\ldots$. & ... & $\ldots$ & & 667 \\
\hline English ... & ... & ... . . & $\ldots$ & $\ldots$ & 550 & 637 \\
\hline Turkish ... & $\ldots$ & ... . & $\cdots$ & $\ldots$ & 1041 & 1137 \\
\hline Egyptian & $\ldots$. & ... $\quad$. & $\ldots$ & $\ldots$ & 844 & 926 \\
\hline Greek $\quad \ldots$ & $\cdots$. & ... $\quad$. & $\ldots$. & $\ldots$ & 700 & 810 \\
\hline English ... & ... & ... .. & $\ldots$ & $\ldots$ & 695 & 756 \\
\hline$" \quad \ldots$ & $\ldots$. & ... $\quad$. & $\ldots$. & $\ldots$ & 1022 & 1175 \\
\hline Egyptian & $\ldots$. & ... . & ... & $\ldots$ & 530 & 599 \\
\hline Turkish ... & $\cdots$. & ... .. & ... & $\ldots$ & 987 & 1181 \\
\hline,$\quad \ldots$ & $\ldots$. & ... $\quad$. & ... & $\ldots$ & 1175 & 1506 \\
\hline Egyptian & $\ldots$ & ... $\quad$. & $\ldots$. & $\ldots$ & 420 & 607 \\
\hline English ... & ... & $\begin{array}{ll}\ldots & . .\end{array}$ & $\ldots$. & $\ldots$ & 350 & 390 \\
\hline Egyptian & $\cdots$ & $\ldots \quad$. & $\ldots$. & $\ldots$ & 713 & 790 \\
\hline Turkish ... & ... & $\ldots \quad .$. & ... . & $\ldots$ & 1220 & 1738 \\
\hline English ... & ... & ... $\quad .$. & $\cdots$. & $\cdots$ & 579 & 731 \\
\hline Egyptian & ... & ... $\quad .$. & ... . & $\ldots$ & 549 & 635 \\
\hline Greek $\quad \ldots$ & $\ldots$ & ... $\quad .$. & ... . & $\ldots$ & 664 & 698 \\
\hline Turkish ... & ... & ... $\quad .$. &... & $\cdots$ & 1000 & 1013 \\
\hline Fgyptian & $\ldots$. & $\begin{array}{ll}\ldots & . \cdot\end{array}$ & ... . & $\ldots$ & 5 & 5 \\
\hline Turkish ... & ... & $\ldots \quad$. & $\ldots$. & $\cdots$ & 700 & 924 \\
\hline Egvptian & $\cdots$ & $\begin{array}{ll}\ldots & . .\end{array}$ & $\ldots$. & $\ldots$ & 37 & 37 \\
\hline & - & & & & 14,332 & 16,952 \\
\hline
\end{tabular}

It stands to reason that neither shipowners nor quarantine officials can estimate how much money the ship's captain or agent has actually received, nor how many people have died on the passage.

One word in favour of the Mussulman pilgrim may not be out of season, for he is a person who, in my opinion, has been much maligned. My experience of him extends over a period of three years and I confess to a feeling of great respect and liking for the unfortunate person. Treat him well, and above all give him plenty of water, and the supposed fanatic becomes the most docile, easy-going, grateful and polite Eastern gentleman. A friendly nod to a group of these people sitting before their tents will cause the whole lot to rise and salaam with a stately grace and a politeness which are not to be found outside the East. Thei so-called fanaticism is too often the feeling of bitter resentment for the ill-treatment which they have received from the men in whose hands the pilgrim trade has been up to now.

Here I must pause to describe the position of Tor and its advantages as a quarantine post. The port and village of Tor are situated about 120 miles south of Suez on the Sinaitic peninsula at the foot of Mount Sinai. One might almost think that it had been designed for the purpose, as owing to its geographical features, approach is practically impossible except by sea. At the base of Mount Sinai lies a plain, some 12 miles wide and some 10 miles long. At the northern end of this plain lies the little town of Tor founded (it is said) by the Empress Helena when she built the monastery on the mountain. The descendants of the original Greek inhabitants still form the greater part of the population of the place and carry on the work for which it was built-namely, of supplying the monks with fish, fruit, and other necessaries. Up till recentily they made great profit out of the wrecks which frequently occurred along this dangerous coast. There are a few fresh springs around the town and near these are groves of palms, figs, vines, \&c. Over the rest of the plain though water is easily obtainable, it is brackish, and the vegetation is very sparse, serving only to feed the goats of the few natives who eke out a scanty living in this lonely region. 'Though only about 120 miles from Suez by land the absence of fresh water makes the land journey from Tor impracticable exoept for a well-organised camel caravan or a hardy Bedouin. It is therefore useless for any pilgrim once landed at Tor to attempt to escape on foot; and to add to the security of the camp Bedouin ontposts are stationed round whose duty it is to bring back anyone found wandering about. Liven the approach by sea is not altogether easy as the little harbour only affords, shelter to small launches and fishing-boats, the entrance between the coral reefs being narrow. All large steamers have to anchor some distance from the shore, and if any unwary pilgrim were to escape and attempt to swim back. to the ship he would run a fair chance of being caught on the way back by a shark. In addition to the natural security of its position Tor seems specially fitted for a health camp by its climate. Though in the proverbially unpleasant Red Sea El Tor has a most pleasant climate of its own, being sheltered from the land winds by the huge Sinai range, while it gets the full benefit of the north wind which for 300 days in the year blows down the Gulf of Suez. Even at midsummer this refreshing wind makes the heat of the sun tolerable. It is a rugged but very picturesque spot; the little white town stands out brightly against the blue sea and sky; the tents of the camp and the clumps of palm trees make a pretty foreground; while the bare lofty peaks of Mount Sinai, towering in the background, and the range on the western side of the Gulf present all day an endless variety of colours, from pale misty blue at midday to deep pink and purple at sunset. Within the last few years, and thanks to the liberality of the Egyptian Government, the former primitive arrangements have been considerably altered. Three separate landing-stages have been erected leading to three separate disinfecting establishments; pipe-water has been laid down throughout the camp; a railway has been built for the conveyance of luggage and the sick; and by next year a bacteriological laboratory, post-mortem room and-I trust-hospitals, will be built. The pilgrims land in small boats on a jetty, along which rails have been laid, and take their luggage in trucks to the disinfecting station. This lies close to the sea at the head of the jetty and the pilgrims wait in a great covered shed outside until their turn comes to enter the camp. The camp lies a quarter of a mile away and a little railway now takes the heavy baggage and the invalids. This camp is divided into compartments of about 150 metres broad and 250 metres long by fences of wire netting 10 feet high ; the compartments are now about 36 in number and each can hold 500 people easily. They are not, however occupied in succession, but an interval of two empty plots is 
always left between two lots of pilgrims. Thus, sections 1, $4,7,10$, and 13 are in use together, so that in the event of a man trying to join friends in another section he has to climb four fences each three metres high and is sure to be seen running across the intervening spaces. Moreover, in case of plague or cholera breaking out in section 1 all the inbabitants can be moved bodily into section 2 , and there still will be two wire fences and a distance of 150 metres between them and the next lot of pilgrims. At the entrance to each station there is a picket of soldiers and each lot of 500 pilgrims has its complement of one medical man in charge, two supervisors, and a number of quarantine guardians, sweepers, \&c., as well as its own little café, where the pilgrims may buy their food and a few little luxuries. The catering for the whole camp is undertaken every year by one contractor, who competes for this privilege with others of his trade, and the preference is given to the man who can undertake to produce at the lowest rate food of a given quantity and sufficient for a given number of people for a stated number of weeks. Of course, there is a certain amount of grumbling, but the tea, coffee, bread, \&c., sold by these caterers are really of very fair quality. Each day rations are served out at the expense of the Egyptian Government to the very poor pilgrims who cannot afford to purchase food. A great difficolty is to supply such a large number as from 4000 to 6000 people with sufficient water, not only for drinking but also for the ablutions imposed on them by their religion before morning and evening prayers. It must be mentioned that Tor is in the desert and that there is only one well containing sweet water. This difficulty has been recently met by a pumping-station which is worked by steam instead of by hand. The water is pumped into a reservoir at the top of a hill from which pipes run into all the sections, hospitals, \&c. Now that the well has been improved the water is quite clear and sparkling but with a very slight saline taste. The hospitals up to date are primitive, consisting only of tents and a dispenzary, one of the few wooden buildings to be seen in Tor camp; however, there are hopes that more permanent hospitals will shortly be provided. The tents forming the hospitals are divided into four groups, each group being separated from the other by a large intervening space and having a staff of its own. The hospitals are as follows: (1) hospitals for ordinary diseases ; (2) hospitals for gastro-enteric diseases ; (3) hospitals for cholera; and (4) hospitals for plague. Of these the hospital for gastro-enteric diseases is by far the most important, for the number of pilgrims who suffer from dysentery is enormous. Hardly a day [passes but three or four worn-out old men die from dysentery or its complications. Liver abscesses, secondary pyæmia, and intestinal perforations are of frequent occurrence. Typhoid fever, small-pox, syphilis, and all kinds of strange skin affections occur among the contagious diseases; indeed, the camp at Tor is an immense field for pathological research. Besides these cases we get every year a few cases of gunshot wounds in pilgrims who have been attacked by the wild Bedouin tribes of the Hedjaz.

We may now proceed to examine the international regulations which govern the pilgrimage. The regulations are different, according as to whether the pilgrimage $\cdot$ is clean or infected. If the pilgrimage is "clean"-tbat is to say, if neither plague nor cholera is raging in the Hedjaz-the pilgrims are detained at Tor for three or four days and the vessels which bring them undergo the same period of observation. Only those Egyptian pilgrims or pilgrims residing in Egypt who are furnished with a card stating their place of residence are allowed to land at Suez after a favourable medical visit. Foreign pilgrims may on no account land in Egypt, but must return in quarantine through the Canal to their own countries. The transshipment of pilgrims in Egypt is at all times interdicted. It will be noted that nothing is done when the pilgrimage is "clean " except a period of observation. The authorities which decide whether the pilgrimage is "clean" or infected are the Turkish authorities at Jeddah, Mecca, and Yambo ; and it stands to reason that the period of observation of three days is only enforced because the Powers who have signed the Convention of Venice have little confidence in the declarations of the Turkish sanitary authorities. Indeed, this want of confidence is quite justified, for, during my term of office at any rate, the Turkish authorities have never declared the presence of plague at the Hedjaz until the subject had become a matter of public notoriety through other sources. If then the powers rightly refuse to accept the declaration of the Turkish authorities the logical deduction is that all pilgrimages should be considered infected until the pilgrims bad been landed at Tor and found to be healthy. The operations of disinfection should be started at once, so that all infectious material should be destroyed except that carried on the body of the person actually incubating plague or cholera. At present the Convention of Venice does not allow of any precantions to be taken until the disease has broken out. They say: "We suspect these people to bave plague or cholera material with them, but don't you do anything until you have given the cholera and plague bacillus a chance." The consequence is that a pilgrim might inoculate himself from plague- or cholera-infected clothing after leaving Tor and carry plague or cholera into Europe. I do not say that such a case has happened, but judging from the experience of plague in India, where people contracted plague long after leaving India, such an occurrence is only too likely. Similarly, the vessels and crew of the ship are not disinfected.

The regulations with regard to foreign pilgrims not landing in Egypt are excellent but most difficult to apply However, they have been applied in their entirety during the last two seasons. If the Hedjaz is infected with plague all the pilgrims are subjected at Tor to a quarantine of 12 days, beginning only after the disinfection is quite finished. Should there be an epidemic of cholera in the Heoj jaz the quarantine lasts for 15 days after disinfection. The ships carrying pilgrims other than Egyptians then cross the canal in quarantine and return to their respective countries, while those with Egyptian passengers proceed to Ras Abouzoulima and undergo a supplementary observation of three days. The latter are then received at Suez in free pratique after another medical visit.

The regulations appear simple enough and would indeed be so were it not that one had to deal with an enormous mass of people arriving by batches of from 500 to 1000 at a time. I have been not a little astonished by the ease with which gentlemen sitting comfortably in Venice and elsewhere speak of the disinfection of hundreds and thousands of individuals. As a matter of fact no measure is more difficult to carry out successfully on a large scale. The ordinary pilgrim coming from Egypt and the North is in many instances a trader, who combines religion with business and brings back with him a large amount of goods to be sold in his own country. Ten or 12 boxes may form the luggage of such a man and I have seen one pilgrim with no less than 80 boxes of luggage. Most of these goods are not such as would easily carry infection, but still the boxes have to be searched and the dirty linen, \&c., extracted. The pilgrims are landed in batches of 40 and taken to the disinfecting establishment, where their luggage is searched and all the things requiring disinfection are removed. Linen, bedding, \&c., are steamed at $110^{\circ} \mathrm{C}$. for 20 minutes, the maximum temperature being ascertained by an electric-signal thermometer and a maximum thermometer. Shoes, slippers, \&c, are put for from five minutes to half an hour in a 1 in 1000 solution of perchloride of mercury. All water skins are removed and a tin can closed by a cork is provided instead. While the disinfection is in progress and the goods are removed to the clean side of the building the pilgrim is taken to another room where he takes off all his clothing and is provided with a clean shirt. He then undergoes a physical examination by a medical man. This consists of (1) feeling the pulse; (2) an examination of all the superficial glands; and (3) an examination of the tongue. If there is any sign of fever the temperature is taken and the patient, if necessary, is placed in an isolated hut at a distance of half a mile frcm the section. Those who show no signs of disease are tak $\in \mathrm{n}$ to be douched or bathed in warm sea water, a process which appears to give them great satisfaction. The shirt they wore is $r \in$ moved, their clothing (which has been disinfected in the meanwhile) is restored to them, and they are at once marched off with their luggage to the camp where six pilgrims sleep in each tent. The following diagram illustrates the arrangerrent of a section.

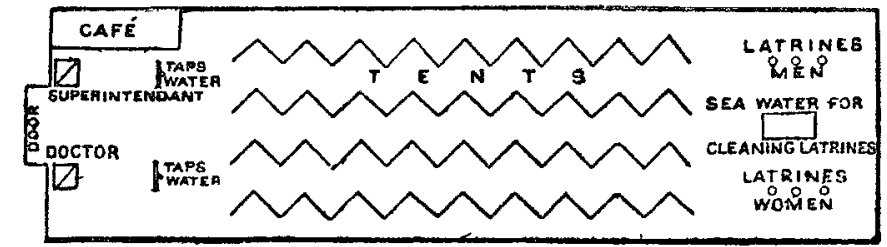


It will be seen that the fresh-water taps are at one end of the section and the latrines at the other, and rather far distant from pilgrims in the first row of tents. This arrangement is shortly to be altered. The latrines have the usual Oriental seat and sea-water is provided for the ordinary ablutions after defæcation. In each section two sweepers see to the disinfection of latrines. As the pilgrim enters the camp his name is taken and every morning the medical man in charge of the section is bound to hold a roll-call to see and examine every pilgrim. The women, who are but few in number, are examined by a lady doctor. The rule is that in case of cholera or plague breaking out the inhabitants of each section shall be removed into the neighbouring empty space after complete disinfection of all their goods and effects. The persons in contact with the patients-that is, sleeping in the same tent-are especially watched and examined night and morning. Luckily, such a case has not presented itself during the last three years. After the period of quarantine is over the pilgrims leave and go in quarantine through the Suez Canal to their respective homes. The Egyptian pilgrims are landed again at Ras Abou Zuneima, a dreadfully hot, close, and stuffy place, half-way between Suez and Tor, where they undergo another quarantine period of three days. The reason for this extra precaution is not obvious, and I am strongly of opinion that this measure should be suppressed at the earliest opportunity. In order to judge of the value of these measures against plague and cholera it is necessary to give an outline of the way in which patients suffering from these diseases carry infection.

In plague it appears pretty clear that the subject of ordinary mild bubonic plague is not infectious in himself, as the bacillus, except in rare cases, does not leave the body in the excreta in mild cases. The patient in a really bad and infectious case of plague is always so ill that few medical men would fail to recognise the serious nature of the disease and stop him from embarking. A person who has got over plague is, in all probability, not infectious. At any rate, I know of no instance in which a case of plague has been traced to a patient who has left the hospital cured. The length of the convalescence also would keep the patient in hospital so long that by the time he left he would be harmless. As the incubation period of plague does not exceed fire days it follows that, provided the rules concerning disinfection are well carried out, provided also that convalescent patients are kept long enough to guard against a relapse, I am of opinion that the measures taken now are sufficient to prevent plague being carried by the pilgrims.

With regard to cholera the case is quite different. We know now that the vibrio choleræ persists not infrequently for as long as 50 or more days, in the evacuations of patients who have had cholera. We know also that during an epidemic of cholera the vibrio choleræ does appear in the stools of persons who at most suffer from slight malaise or diarrhœa, so that the clinical diagnosis of cholera becomes almost impossible in these cases. The only possible way in which this source of error could be eliminated would be by the bacteriological examination of the fæces of every person suffering from diarrhœea. This is clearly impossible for several reasons. In the first instance, quite 50 per cent. of the pilgrims suffer from diarrhoea owing to the bad food, bad water, and the hardships which they have undergone. Pilgrim's diarrhoea is a well-known disease in the East and the term appears to include every form of intestinal derangement, from typhoid fever to cholera. It is clearly impossible to examine the fæces of hundreds of people bacteriologically. Eecondly, among the pilgrims at any rate, there has been found in the intestinal contents of several persons a vibrio which so exactly resembles the vibrio choleræ that it cannot be distinguished from it by the ordinary culture and microscopical tests. It was discovered at Tor in 1896, and Dr. Bitter, Dr. Gotschlich, Dr. Galvani, and myself, who examined the cultures, were of opinion that this was the vibrio choleræ. Later, however, it was discovered that there was a slight quantitative, not a qualitative, difference in the reaction given by the vibrio to $t$ e serum test from the reaction given to the same test by the vibrio choleræ. This microbe was discovered at Tor at a time when from personal observation I can answer for the statement that there was no "clinical" cholera at Tor. The orders had been given that $t$ very case of cramp or vomiting should be at once reported. Every patient coming into the hospital with the slightest intestinal disorder was carefully examined, but not the slightest case resembling cholera was discovered. Whether this microbe is a modified vibrio choleræ or not matters little for our present purpose, but its existence shows clearly that when one has to deal with thousands of persons no practical rule could be framed on the microscopical or bacteriological examination of fæces short of a serum test. The fact cannot be too strongly impressed, therefore, that quite apart from the wilful fraud of those in quarantine and their guardians, quite apart from possible negligence in disinfection, a person can go through a period of quarantine and carry the disease to some other place.

Such are the measures which are taken at Tor against pilgrims. The quarantine station for ships coming from the Ked Sea or the Far East, and which do not carry pilgrims, is at Moses' Wells, a desert spot situated about six miles from Suez on the Asiatic shore of the Gulf of Suez. The establishment consists of a disinfecting station, two hospitals, a small lazaretto for passengers, and a medical man's house, kitchen, \&c. The disinfecting establishment has two huge disinfecting stoves, baths, douches, hot and cold water arrangements, and is quite a model of its kind. ${ }^{2}$ The buildings could not accommodate more than about 50 passengers at most, so that in the case of a big passenger steamer arriving from an infected port and seeking pratique in Egypt quarantine must be carried out on board. All ships arriving from the Red Sea are indiscrimately subjected to medical examination at Suez. Vessels from a cholera- or plague-infected port are subjected to measures which vary according to circumstances and which are applied as follows.

Cholera-infected ships.- (a) If the vessel be healthy (that is to say, if there has been no case on board at the time of departure or during the passage), it is admitted to free pratique after the medical visit, provided that five clear days have elapsed from the time of leaving the infected port. If the passage has been made within that time the ship is kept under observation until the five days are over. The passengers must remain on board or be landed at Moses' Wells and undergo medical examination during their stay. The Council has the right to order disinfection to be done. This arrangement was specially made by the Egyptian Board with regard to healthy vessels bailing from the Mediterranean, and has hitherto been applied to the same class of vessels from the Red Sea ports. (b) If the ship be suspected (that is, if it had on board a case of cholera at the time of leaving port or at some time during the journey, but not during the last seven days), it is allowed to traverse the Suez Canal in quarantine, on condition of having a medical man and a disinfecting stove on board. Should it not have these it must be retained at Moses' Wells, near Suez, long enough for the disinfection of dirty linen and other suspected objects, the disinfection to be carried out at the sanitary station there. Afterwards the ship may cross the Canal in quarantine. An exception is made if the vessel is a mail boat or passenger boat without a disinfecting stove but carrying a medical man, when it may pass through in quarantine if the sanitary authorities are fully satisfied that the ship was disinfected either on leaving the port or during the passage. A vessel under the same circumstances which has made a journey of more than 14 days' duration, is given free pratique after being disinfected. If the passage has taken less than 14 days the boat and passengers are kept for 24 hours at Moses' Wells and are then given pratique after disinfection. When the cholera appears among the crew only the disinfection is applied to the soiled linen of the crew alone and is extended also to the crew's quarters. (c) If the ship be infected (that is, if a case exists or has existed on board during the past seven days), and if it carries a medical man and a disinfecting stove, it must return to Moses' Wells, where the sick are disembarked and the dirty linen both of the rest of the passengers and of the crew is disinfected on board. Should the cholera have broken out among the crew exclusively, the disinfection is confined to their dirty linen and to the linen of their quarters. All persons who have come in contact with the sick are also disembarked and are kept at Moses' Wells until the completion of five days from the date of the last attack on board. The vessel also must remain there until the fifth day after the last attack, but it is allowed to traverse the Canal in quarantine after landing the

2 I have no besitation in saying so, as I bad nothing to do with the desioning or building of it. 
sick and suspected persons and undergoing disinfection. This disinfection is carried out only in the part of the vessel with which the sick persons have come in contact and in the sick bay. The time that the ship is being disinfected is included in the time that it passes under medical observation. If the boat carries neither disinfecting stove nor medical man it must go to Moses' Wells to undergo five days of medical observation to date from the last case discovered on board. The sick and suspected are disembarked and isolated in the hospital. The other passengers are also landed and isolated in as small groups as possible in order that the whole may not become liable should cholera break out in any one group. A thorough disinfection of the contaminated vessel is carried out. The dirty linen, vessels, and clothes both of passengers and crew are alike disinfected. The merchandise is not landed. The passage through the Canal in quarantine is granted after the disembarking of the sick and suspected and when the disinfection has been efficiently carried out.

Ships coming from a plague-infected port.-(a) Healthy ships are admitted to free pratigue after the favourable medical visit. They must in all cases have completed, or be about to complete, 10 clear days from the time of leaving the last plague-infected port. The dirty linen of the crew and passengers is disinfected. The medical visit is always paid during the day. Healthy vessels may also pass the Canal in quarantine if continuing to make up their 10 days. (b) Suspected ressels-namely, those on which a case of plague occurred on the date of departure or during the voyage but where no new case has supervened for 12 days pastare allowed to enter the Canal in quarantine on condition of having a medical man and a disinfecting stove on board. If they do not carry both they may go across the Canal only after the dirty linen and other susceptible objects have undergone disinfection. Postal or passenger boats without a disinfecting stove but carrying a medical man may pass through in quarantine in cases where the sanitary authorities are satisfied that disinfection has been carried out during the voyage. Suspected boats which have made a passage of more than 14 days' duration are admitted to free pratique after disinfection. If the passage is less than 14 days the vessels with their passengers are detained at Moses' Wells to complete 10 days, after which they are given pratique after being disinfected. (c) Infected vessels (or those which either have a case of plague on board or have had one within the past 12 days) are kept at Moses' Wells where they land their sick. If they have a medical man and a stove the soiled linen of the crew and passengers are disinfected on board. When plague has broken out among the crew the linen of the crew and of their quarters is alone disinfected. At the same time all persons who have been in contact with the sick are landed and detained at Moses' Wells for 10 days after the outbreak of the last case on board. The vessel itself must remain 10 days at Moses' Wells after the last attack on board, but it may go throngh the Suez Canal in quarantine after landing the sick and suspected persons and after being thoroughly disinfected. This disinfection is carried out only in the part or compartment of the ship and in the section of the hospital to which the sick persons have had access. The time taken up by disinfection is included in the period of medical observation. If the vessel have neither medical man nor disinfecting stove on board it must return to Moses' Wells to complete (as well as the passengers) a term of 10 days from the outbreak of the last case. The sick and suspected are isolated in a hospital; the rest of the passengers are isolated in groups of as few in number as possible in order that all may not be liable in case the plague should appear in any particular group. A thorough disinfection of the infected ship is undertaken; the dirty linen, the vessels and utensils, and the clothes of the passengers and crew are alike disinfected. The merchandise is not landed. The passage of the Canal in quarantine may be granted after the landing of the sick and suspected and the disinfection of the ships have been entirely carried out.

The Board has no power over merchandise going through the Canal, but the rules with regard to merchandise coming into Egypt from plague- or cholera-infected ports are as follows. Soiled body-linen and garments, bedding, carpets, sacs, and embroideries may be disinfected or their entrance may ve prohibited. The same rules apply to any animal refuse, such as hairs, untanned skins, hoofs, \&c. Silks and uncarded wools may also be prohibited. Taking merchandise first, it is difficult to understand why animal refuse, silks, or wools should be submitted to any measures, as I am not aware that animals get plague or cholera. The argument that they might bring plague or cholera because they have been stored in dirty places applies just as well to every other form of merchandise. I do not understand why any restrictions should be placed on any merchandise except soiled linen and rags. The East has been infected with plague for more than three years and with cholera for many more years; thousands and thousands of tons of merchandise have gone from infected ports to all kinds of places and so far not a single clear case of infection has been traced to merchandise. I am not aware that a single porter who unloads ships in London or Liverpool has contracted plague or cholera ; and when plague has broken out on board ships it has attacked firemen and stewards chiefly who have nothing to do with the merchandise. The same results apply to rats, against which $I$ notice that some nations are taking measures. I am not aware that up to the present any ships have arrived at Suez complaining of the presence of dead rats on board. We have not heard that the rats in London or in foreign ports have begun to suffer from plague, although they must have been in zuntact with rats comag from infected ports. Nay, more, there is evidence that on several of the ships actually infected with plague no special mortality among the rats has been noticed. Up to the present moment the evidence that rats may carry plague from place to place or country to country is purely negative.

We may now proceed to examine critically the measures which affect the passengers. Persons landed from plagueinfected ships are allowed to go to their homes after their period of quarantine is over but their names and addresses are taken down. The native passengers are visited for a certain length of time by the officers of the Sanitary Department of the Interior. The measure is one highly to be commended. The disinfection of the ships as ordered by the Convention of Venice is one which it is not always easy to carry out. The ordinary methods of squirting on pulverised sublimate solution is one in which personally I have no confidence whatever. In one case a ship was disinfected twice in that way and plague cases still occurred, for the fact is that sublimate has practically no penetrating power whatever on the greasy planks of the sick bay or the crew's quarters. In the absence of a good antiseptic a good washdown with soap and water and subsequent flooding with the hose would be far more efficient, as it would, at any rate, mechanically remove the microbes. The best antiseptic for the purpose, however, appears to me to be a 5 per cent. solution of carbolic acid to which a sufficiency of soft soap is added. The water is first heated to boiling-point and the carbolic acid and soft soap are slowly added under constant stirring. This is then well scrubbed in with handbrushes. Those using it should wear indiarubber gloves, as it blisters the hands dreadfully. The clothes which have to be disinfected are always to be disinfected by steam under pressure.

It has already been noticed that only a certain part of the ship and the clothes of the crew are disinfected and that in some cases this disinfection may be carried out without extraneous help by the people on board the ship. Clearly, such rules are little better than a dead letter, for the captain of the ship, in order not to delay his ship, will try to limit the disinfection to the smallest possible space. The crew will hide their clothes-for to a man they believe that these will be spoilt by "fumigation"-so that the chances of disinfection being of any use are minimised. The disinfection on board ship, carried out by the ship's people under the supervision of the ship's medical officer or chief engineer is, in my opinion, little better than a farce. The passengers do not think of giving up their soiled linen because it is too much bother and they fear that it will be spoilt; and, in one case at any rate in which $I$ had the opportunity of watching the operation of disinfection as a passenger, the disinfecting stove was not even screwed down. In other two cases the passengers laughingly boasted how they had each given one or two pairs of socks or handkerchiefs, or, perchance a shirt, which represented their soiled linen for a voyage lasting almost a week. Similarly on landing the medical officer is simply dependent on the word of the passengers as to whether they give him all their dirty linen or not. He cannot, and indeed will not, rummage about the trunks to see that the people have given up their soiled linen, and certainly the passenger's word on such a point is not to be trusted.

It is clear from the remarks which I made with regard to the measures taken at Tor that at present there is nothing to 
prevent ships carrying persons in the incubation period of cholera and plague to go through the Canal to Europe, and that in the end the ultimate measures to be taken must be taken in Europe.

An experience of three years of quarantine work is perhaps not sufficiently large to entitle me to give an opinion on measures which have been signed by the plenipotentiaries of the great and small Powers of Europe. Nevertheless, I may be allowed to express tentatively the opinion which I have formed respecting the way in which the quarantine measures recommended by the Powers do work in practice. At any rate, I have had ample opportunities of seeing that. Now, I am very strongly of opinion that any measure which is recommended should be such that it can be applied. With regard to the pilgrimage, the measures are fairly satisfactory because the pilgrims at Tor are, so to speak, in our power and because time is of little object and the disinfecting plant is sufficient. With regard to the measures for passengers entering Egypt a good deal can be done, because here again the measures can be applied with a certain amount of success. A captain might possibly hide a case of plague or cholera, but should the case be fatal suspicion would be aroused by the very fact of there having been a death on board. The other measures which are taken for suspected and infected ships which transit the Canal in quarantine or are detained for disinfection at Suez, are, in my opinion, useless for the most part because they are avoided and, as long as human nature is what it is, will be avoided. The measures which might be carried ont with a fair amount of success are those which affect the sick person only, and not the crew, passengers, and ship. A ship's captain has no objection to landing a person sick with plague and cholera and his kit. He will only be too glad to do so, as experience has shown; nor will he have much objection to his cot and neighbouring cots being disinfected. But he will try to oppose any landing of men who have been in contact with the patient, because if the sick man has been in the same room as his companions the captain might lose half his crew by the application of this method. I know of one captain who stoutly maintained that no one but the steward had visited the patient, when the medical officer had had ocular evidence that most of the crew had been in contact with the sick man. Similarly with disinfection, the captain does not object to the patient's kit and bedding being disinfected or thrown overboard, but most of the crew and passengers will do their very best to hide everything which they can possibly hide. And, indeed, there is no reason why they should not, for the measure is absured in itself.

These measures of wholesale disinfection are really based on the old idea that cholera and plague are conveyed by air, and on that theory it is supposed that a ship becomes infected from end to end by a plague or cholera case. But now that it is known that a cholera or plague patient is only dangerous by his dejections it is high time that such measures should be abandoned. The disinfection should be strictly limited to $(a)$ the linen of the patient or the bag or trunk in which the linen has been placed and to (b) the cot and cabin of the patient.

With regard to the landing and segregation of the contacts it is an excellent measure theoretically, but from the practical point of view in no case so far have $I$ seen it do any good.

In the case of the Mehalla-a ship coming from Jeddah, in which a case developed plague the day after its arrival at Suez, where it took pratique-the ship's medical officer, who would certainly not have been landed had the ship gone through the Canal in quarantine, got plague and died. Four of the crew afterwards showed suspicious symptoms, although the ship had meanwhile been disinfected twice with sublimate, but these patients were in no particular relationship to the patient and would certainly not have been considered as contacts. Their mode of infection was doubtful. No dead rats were found on board till after disinfection with sublimate. There was no evidence to show that these rats had died from plague, but they had probably died from the disinfectants scattered about the ship.

The following is the number of the ships of which $I$ bave notes which had plague or cholera on board before getting to Suez and the history of the contacts. The s.s. Glanson had eight cases of, and four deaths from, cholera on board from April 27th to May, 1895 . The vessel arrived at Suez on May 21st, 1895. No contacts were landed. The s.s. Dilwara had one case of plague on board on March 18th, 1897. Three persons landed. There was no case of plague among the contacts. The s.s. Britannia had three cases of cholera on board. Two of the sick were landed at Moses' Wells on August 16th, 1897. No contacts were landed. The s.s. Caledonia had two cases of plague on the day of its arrival at Suez. Two contacts were landed but were not attacked. The s.s. Dictator had two cases of plague on board when the ship arrived at Suez. All the members of the crew were kept 10 days at Moses' Wells, but no case of plague occurred among them. It will be noticed that in two cases the contacts are conspicuous by their absence and that, as a matter of fact, not a single person isolated as a contact developed plague or cholera afterwards. A strict logician would not fail to argue that contacts are less liable to plague than others.

To conclude, I believe that the measures ordered by the Convention of Venice for the pilgrimage are adequate so far as plague is concerned. To a great extent the regulations can be carried out with a fair prospect of stopping an epidemic of plague and of sending the pilgrims out free from plague bacilli. With regard to cholera I am of opinion that a quarantine of several weeks will not ensure safety. One may diminish the chances of infection but not abolish them, and the only safety is the watching of the pilgrims after their arrival in their homes. Similarly, the measures applied to the passengers landing in Egypt can be applied with a fair hope of success. The transit of ships through the Canal in quarantine affords some security to Egypt but none to Europe, as experience has repeatedly shown.

The measures of disinfection bearing on the linen of the whole of the crew and passengers are, in my opinion, bound to be a failure, because, short of searching and emptying out a whole ship, many of the articles will be concealed. Further, I am of opinion that such a measure is not expedient and that the disinfection should be limited to the linen, clothing, and quarters of the sick patient. Similarly, no person should be landed except those whose temperature is raised or who are actually showing symptoms of plague or cholera. Experience has shown that those who have been landed because they had been in contact with patients did not get either plague or cholera.

Lastly, my opinion on questions of quarantine, ship disinfection, \&c., is that it is better to do a little well and thoroughly than a great deal badly. That when we remember that it takes five minutes for a surgeon to clean bis nails, the disinfection of a large number of persons is not likely to be done satisfactorily in a short time. The great danger is the patient, the things in his immediate neighbourhood, and his soiled linen, and it is comparatively easy to deal with them; but when an attempt is made to enforce measures which affect healthy people and entail pecuniary loss the door is open to every form of fraud, concealment, bribery, and corruption. Personally, I feel sure that we should be far more likely to know the truth were it not for the fear of delay produced by quarantine measures. Hence I am of opinion that all measures for ships going through the Canal in quarantine should be abolished except the landing of the sick and the disinfection of the sick person's quarters and linen.

Alexandria.

\section{SOME NOTES ON SERO-THERAPY.}

\section{BY H. W. MILLS, M.R.C.S. ENG., L.R.C.P. LoND.}

THE cases on which these notes are based consist of one case of tetanus treated with anti-tetanic serum, one case of puerperal fever treated with anti-streptococcic serum, and 76 cases in which anti-diphtheritic serum was injected27 times for the treatment of existing diphtheria and 49 times prophylactically in cases of relatives who had been in close contact with diphtheritic patients.

The reporting of cases in which anti-streptococcic and antitetanic serums were used needs no apology; all such cases, successful or not, should be reported, as the serums mentioned are still on trial. And the same remark will apply to the prophylactic use of anti-diphtheritic serum; if it be conclusively shown that the latter confers complete and undoubted immunity against diphtheria-even though it be for a short period only-it becomes the duty of the medical 